\title{
Islamic eco-cosmology in Ikhwan al-Safa's view
}

\author{
Muhd. Abdullah Darraz
}

Program Director of Maarif Inst itute for Culture and Humanity, Jakarta

E-mail: darrazophy@yahoo.com

\begin{abstract}
This research aims to describe the root cause of ecological crisis happening at the moment in terms of the cosmological-metaphysical views, by doing research on the thoughts of a classical Muslim philosophical scientist group in 10th century AD called I khwan al-Safa'. To the author, I khwan al-Safa' has a clear idea in viewing the universe holistically and intact as it is. Actually, this non-reductive view was the typical main feature of medieval Islamic classical thought. However, the main reason of choosing the works of I khwan al-Safa', especially their magnum opus Rasa'il I khwan al-Safa'? in the research is that I khwan al-Safa' has put a lot of attention on the "wisdom of universe" in the ontological and epistemological structure of knowledge that were developed in their work. With the main concepts such Love of Universe and Soul of Universe, I khwan al-Safa' have given a holistic vision about the wisdom of the universe and the wisdom of the environment itself.
\end{abstract}

Pengkajian dalam artikel ini bertujuan untuk menguraikan akar masalah tejadinya krisis ekologi yang terjadi saat ini dengan berangkat dari titik pijak berdasarkan perspektif kosmologis-metafisik. Yakni dengan melakukan penelitian terhadap pemikiran kosmologi kelompok keilmuan-filosofis muslim klasik abad ke-10 M yang bernama I khwan al-Safa'. Bagi penulis, I khwan al-Safa' memiliki pemikiran yang jernih dalam melihat alam semesta. Yakni melihat alam secara holistik dan 
utuh sebagaimana adanya. Sebenarnya pandangan khas yang non-reduktif ini menjadi ciri utama pemikiran klasik I slam abad pertengahan. Namun pemilihan penelitian terhadap pemikiran I khwan al-Safa' -terutama dalam karya magnum opusnyaRasa'ł I khwan al-Słafa'> ini, lebih disebabkan karena kelompok ini bagi penulis, telah menaruh perhatian yang sangat kuat terhadap "kearifan alam" dalam struktur ontologis dan epistemologis keilmuan yang dikembangkan dalam karya mereka. Dengan menguraikan beberapa konsep utama dalam kosmologi I khwan al-Safa', seperti alam sebagai sebuah kesatuan, jiwa semesta, dan cinta semesta, kita akan melihat bagaimana I khwan al-Safa' memberikan sebuah visi holistik mengenai kearifan alamsemesta dan kearifan lingkungan itu sendiri.

\section{Keywords: Ikhwan al-Safa; Cosmology, Ecological crises; Holistic worldview; Universe soul; Universe love}

\section{Introduction}

Disasters did not happen merely as natural phenomena. It happened as a cause and effect cycle. The cause of the disaster is environmental destruction happened everywhere, as a result of modern man conducts. ${ }^{1}$ According to Langdon Gilkey, "Our modern relations to nature, and behind them our attitudes toward and understanding of nature, have disclosed themselves as disasters".2 This happens because the foundation of modern world has been built on empirical-scientific worldview that perceives nature as raw material for our use, an object of dubious human purposes. ${ }^{3}$ Furthermore, modernity supported by modern science provides the intellectual legitimacy for the industrial and commercial exploitation of nature.

${ }^{1}$ The Muslim philosophers such as Farabi, Ibn Sina, Khwajah Nasir al-Din al-Tusi uphold a doctrine of causality and consider every phenomenon in nature to be the effect of a set of causes. See Seyyed Hossein Nasr, Islamic Life and Thought, London: George Allen \& Unwin Ltd, 1981, 97.

'Langdon Gilkey, Nature, Reality, and the Sacred The Nexus of Science and Religion, Minneapolis: Augsburg Fortress, 1993, 79.

3Langdon Gilkey, Nature, Reality, and the Sacred ..., 1 
Ecological crisis and environmental destruction happens because of imbalance and disharmonic relations between man and nature. Man treats nature unfairly and makes natural imbalance. Man has failed in understanding the meaning of the existence of nature. Therefore, Seyyed Hossein Nasr points out that the problem of ecological crisis is the problem of intellectual and spiritual dimensions, the crisis of human understanding and spirituality in their interaction with nature. ${ }^{4}$ According to Osman Bakar, the root causes of the progressive destruction of the natural environment are to be found in the modern abdication of a spiritual vision of nature. ${ }^{5}$

Martin Palmer says that ecological crisis is a crisis of thought. ${ }^{6}$ Lynn White, J r. (1907-1987), an American Historian, affirmed the similar thing in her writing The Historical Roots of Our Ecologic Crisis. She stated, "What people do about their ecology depends on what they think about themselves in relation to things around them. Human ecology is deeply conditioned by beliefs about our nature and destiny-that is, by religion".7

The problem of ecological crises is human failure in understanding the existence of nature completely. Human never defined nature as it is. The understanding of modern man on nature is reductive, it based on destructive worldview from mechanism (mechanistic worldview), secularism, anthropocentrism, materialism, utilitarianismand capitalism. ${ }^{8}$

\footnotetext{
${ }^{4}$ Seyyed Hossein Nasr, Man and Nature: The Spiritual Crisis in Modern Man, ABC International group,Inc, 1997, 3-4 ; Gilkey, Nature, Reality and the Sacred..., 80; also see Osman Bakar, Environmental Wisdom for Planet Earth: The Islamic Heritage, Kuala Lumpur: Center for Civilizational Dialogue University Malaya, 2007, 12.

${ }^{5}$ Osman Bakar, Environmental Wisdom for Planet Earth..., ix.

${ }^{6}$ Cited by Husain Heriyanto, Respon Realisme Islam terhadap Krisis Lingkungan, in (Fakhruddin M. Mangunjaya,dkk (ed.), Menanam Sebelum Kiamat: Islam, Ekologi, dan Gerakan Lingkungan Hidup, Jakarta: Yayasan Obor Indonesia, 2007, 88.

${ }^{7}$ Lynn White, Jr, “The Historical Roots of Our Ecologic Crisis", Science, Volume 155, Number 3767, (10 March 1967), 1205.

${ }^{8}$ Husain Heriyanto, Respon Realisme Islam terhadap Krisis Lingkungan..., 86.
} 
Mechanistic view is believed to be originated from The Father of Modern Philosophy, Rene Descartes (1596-1650) who declared that universe is nothing but a machine. In substance, universe has no purpose, no life, and no spirituality. The universe works in accordance with the laws of mechanics, and every substance in the universe can be explained in terms of its structure and motion of its parts. ${ }^{9}$

Not only to the universe, Cartesian's mechanistic view also extended to the living organisms like plants and animals. To her, animals and plants are no more than just machines. ${ }^{10}$ This view has changed the picture of nature from organic to mechanistic driven by the law of nature. This affects human attitude when it comes to treating nature and the environment. Human has been legitimized to do the nature exploitation and manipulation. In the name of the science, the whole universe and its entities is legitimate to be conquered and controlled.

The secularism view whispered after the Industrial Revolution and the European Renaissance is no other but to liberate the nature out of its metaphysical and spiritual connection. The process of secularization of the universe is a process of desacralization of the nature, so nature can be casually treated. ${ }^{11}$ This secular view has separated nature from its holy boundary. The nature sacred values have been vanished. This is why human tends to treat the nature carelessly and its life recklessly. The secular thinking has turned nature into 'stained-whore' whose life can be exploited haphazardly.

Anthropocentrism has put nature as a marginalized peripheral entity. Cosmically, nature is no longer important and under human power. In anthropocentrism, human is the center of all things; therefore hu-

${ }^{9}$ Fritjof Capra, Titik Balik Peradaban..., 52.

${ }^{10}$ Fritjof Capra, Titik Balik Peradaban..., 52-53.

${ }^{11}$ Syed Muhammad al-Naquib al-Attas, Islam dan Sekularisme, Bandung: Penerbit Pustaka, 1981, 21, 48-54. 
man is seen as the king and ruler of the universe. Human has the right to treat the nature arbitrarily, including doing the exploitation and environmental destruction are legitimated by this anthropocentric system.

Materialism states that nature is inanimate, it has no life. Nature is like a big machine which its existence should be beneficial for human. Just like a machine, nature can be exploited to its highest capacity without having to be empathized or sympathized with nature, for it is considered to be lifeless.

Meanwhile, utilitarianism states that everything that has use value for human existence can be deployed. Again, this is another view considering the value of nature for human purposes only, without considering the other aspects inherent in nature. To benefit certain small group of people, nature is extensively exploited. This view is a continuation of capitalism view stating that nature is a great asset to human life that can be exploited extensively. In a capitalist system, nature is put as the profitable economy commodity to certain small group of human.

If we consider, the modern cosmology from which the above views derived is no longer comprehensive. In this cosmology, the dimensions of spirituality and its metaphysical basis have been uprooted. ${ }^{12}$ More specifically, modern man has reduced the hierarchy of reality into a flat empirical reality. So they have perceived nature merely as an independent entity having no relation with spiritual and metaphysical world. The above view will consider the natural life as an inanimate object, and therefore they treat arbitrary. The negative impact of this outlook is that natural life is threatened, and gives rise to various environmental and ecological crises in this world. SimakBaca secara fonSimakBaca secara fonetik

It has been explained that the ecological problem today is caused, one of them, by the non-holistic modern cosmology view, ignoring the

\footnotetext{
12S.H. Nasr, Man and Nature.., 23.
} 
spiritual and metaphysical dimension. Therefore, a new ecological view based on holistic cosmology needs to be found and formulated. In regard with the needs, the author proposes a concept named ecocosmology. The concept is first introduced by Henryk Skolomowski (born in 1930 in Warsaw, Poland). This concept seeks to portray the cosmos "in new terms" that emphasize that the symbiotic, cooperative, just, and equitable structure of the human world is not an aberration, but a natural consequence of the human response to "the cosmic force" that created the planet, its life forms, and the human species. More specifically, Skolimowski asserts that it is necessary to develop a system of values and a concept of the human which coherently fit the image of the reverential universe in which we act in a participatory manner. ${ }^{13}$ This image of a "reverential universe" is unique and powerful, suggesting a human conduct and orientation toward the universe that serves as an antidote to the dominant tendency of human relation to the planet and its cosmic home arbitrary, relativistic, greedy, slothful, and essentially self-serving ways. Skolimowski's eco-cosmology emphasizes the majesty and power of the universe as well as the constraints it imposes - but it does so using imagery that is inherently spiritual in nature.

However, to the author, Skolimowski's eco-cosmology view still leaves some problems behind. The concept was not based on a clear divinity metaphysic. The focus was more to the relationship between man and nature and all its greatness and power. It is the author's concern that this kind of view, if not framed by a firm divinity, will create a defect on cosmology and ecology view, susceptible from meaning and holistic and metaphysic values reduction.

\footnotetext{
${ }^{13}$ Edward T. Wimberley, Nested Ecology: The Place of Humans in the Ecological Hierarchy, Maryland: The Johns Hopkins University Press, 2009, 84-85.
} 


\section{Scope and method of the study}

It is important for the author here to propose and emphasize the ecocosmology concept based on the tawhid principal in Islam; an Islamic eco-cosmology which is able to draw the clear relationship between God, human, and nature in accordance with viewing the nature holistically and organically. By so, human actions to nature can turn into something fairer, more friendly and balanced.

In connection with the background of the severely globalized ecological problems, this article would like to offer one solution in a more holistic worldview taken from the classic Islamic cosmological thinking from I khwan al-Safa'.

In this matter, the author tries to propose the eco-cosmology concept by Ikhwan al-Safa', a community of philosophers and theosophists (hukama'). The choice of I khwan al-Safa's eco-cosmology concept is based on the reason that this community has a strong commitment on "wisdom of the universe" based on holistic divinity concept. Ontologically, I khwan al-Safa' acknowledged the hierarchy of existence started from God as the source of all existent, rational-metaphysic entities and physical universe. The physical universe cannot be separated from metaphysics entities and the existence of God. Therefore, universe, in the view of I khwan al-Safa', is not only the physical but also the one with metaphysic and spiritual dimension.

Academic world in Indonesia still lacks of the study of Ikhwan alSafa's thought. Even though many ideas and philosophical thinking of Ikhwan al-Safa' are highly relevant to contemporary problems, but they are still deeply and unspreadly explored. ${ }^{14}$

\footnotetext{
${ }^{14}$ Beside, Ikhwan al-Safa's thought is not a dead thought. It is an ever-living thought. This is what makes Ikhwan al-Safa' thought can be assumed as a perennial way of thinking which is relevant with the today's context. One of them is the thought on nature and ethics towards
} 
I khwan al-Safa' has put efforts on systematizing philosophical themes in Islamic scientific tradition through their masterpiece, Rasaid I khwan al-Safa'? This work is believed to be one of the earliest scientific encyclopedia in the Islamic world besides the ones written by al-Farabi ( $d$. 339 H) entitled Hisaral-'Ulu $m$ and by Abu Hatim Muhammad ibn alHibban Busti (d. 354 H) Kitab Wasf al-'Ulum. Rasaxil Ikhwan al-Safa' is the third scientific encyclopedia to be written in Islamic scientific tradition. ${ }^{15}$ Since then, we saw a lot of scientific-philosophical encyclopedias written by Muslim scientists and philosophers, including the Kitab alShifa'> of Ibn Sina. Ikhwan al-Safa' philosophy is assembled on the foundation of a holistic epistemology, which combines the epistemology of the empirics, philsophers, and Sufi.

One of the focuses of this research is the ecological view of Ikhwan al-Safa' which is based on their cosmology. I khwan al-Safa's cosmology can be obtained from the philosophy of nature which became one of the major concerns of Ikhwan al-Safa' in their masterpiece, Rasa'il. The philosophy of nature is trying to express the view of philosophers, including the I khwan al-Safa' on nature and universe. I khwan al-Safa's views on nature affirm the commitment to ecological awareness and the wisdom to protect the environment. This is based on the concept of Tawhild as the root of Muslim worldview and the explanation of the substance hierarchy which puts God as the One. The meaning of the principle of Tawhild is the Unity of God. Unity may be understood at various levels or conceived as encompassing various domains of cosmic existence and all entities in the universe.

environment, which is a contextual thought in responding to the current contemporary problems. See 'Atif al-'Iraqi, Introduction to Sabir Abduh Aba Zayd Muhammad, Ikhwan al-Safa'’ Dirasah Tahlikityyah Muqaranah, Cairo: Maktabah Madbuli, 1999, 10. 
The reality of plural substances comes from and begins with the One Reality. The concept of Tawhild which means the unity of God is a foundation for the unity of the cosmos view or the unity of nature or universe; even it could be particularly derived into the concept of the unity of living species on earth or the unity of the human body. ${ }^{16}$

Here we are interested in the implication of this concept for our understanding and appreciation of ecology and the environment. From this idea, the scientific tradition of Islam has made the necessary ecological inference from the idea of Divine Unity, which is al-Tawhid. It has termed the ecological principle in question the "Unicity of Nature". ${ }^{17}$

The idea of unicity of nature is derived from the application of the principle of al-Tawhild. The idea is understood to mean the interrelatedness of all things that exist in the natural world.

In connection with this idea, I khwan al-Safa' belief universe, as a whole, constitutes a unity since its constituent parts are related to each other in numerous ways and through numerous laws. They speak of the unity of the natural world, the unity of the universe or the unity of the cosmos. They affirm that the macro cosmos or the great universe (al-'Alam al-Kabir) is one entity. ${ }^{18}$

I khwan al-Safa' affirms the principle of Tawhid as the root for the emerging of the existence plurality outside the reality of the One and harmony and order of universe (tartib and nizam) created by Him. To the Ikhwan al-Safa', the emerge of these plural entities compunded from the One Absolute Reality is like drafting figures started from num-

\footnotetext{
${ }^{15}$ Ahmad Zaki Pasha, Mausu'ah al-'Ulu m al-'Arabiyyah wa Bahthn 'an Rasa'il I khwan al-Sąa', Bulaq, Egypt: al-Mathba'ah al-Amiriyyah, 1308 H, 13-14.

${ }^{16}$ Osman Bakar, Environmental Wisdom..., 25.

${ }^{17} \mathrm{~S}$.H. Nasr, An Introduction to Islamic Cosmological Doctrines, Cambridge: Harvard University Press, 1964, 4-5.

${ }^{18}$ I khwan al-Safa', Rasa'il I khwan al-Safa'; Qum: Maktab al-A'lam al-Islami, 1405, IV, 273; See also, al-Risalah al-J ami'ah, Beirut: Dar Shadir, 1974, 534.
} 
ber One. ${ }^{19}$ Number one is the base of the numbers two, three, four, five, and so on. So that is how the existence of God became the base of the existence of entities outside of Him. But the One God is not only limited as a source for the existence of another entity in this compound, but also to the creator of harmony and order among numerous and diverse entities, so this numerous and compound universe lives in harmony and order created by Him.

Ecological commitment of Ikhwan al-Safa' further stated in their thought about universe, namely by positioning universe as great man. This is the umbrella concept of ecological view of I khwan al-Safa'. On one hand universe is regarded as human, then Humanism should not harm nature which is also human. On the other hand, human is seen as small universe, which is part or subsystem of universe, and not vice versa. They added, although human is part of universe, but humans are the most noble and most perfect part of universe compared to other pieces of the universe. Human is the overview of the universe. In human, all elements of the universe are contained.

In Ikhwan al-Safa's view, universe means man, but it also means great man. Like man, so that universe has life, universe also has intellect ('aql) and soul (nafs). The wholeness of universe's soul was called "universal soul". Whereas "universal intellect" is the intellect that has by the universe, which is divine force that supporting the universal soul. The universal natural forces are the power of universal soul that flows on to the body of the universe, which acts as the mover-controller of it. Furthermore, Ikhwan al-Safa' states:

"By this it is quite clear that the process of natural law and all its matter to all the body that lies inside it with its variety, its beauty, and its different accident is also worked to human body or animal

${ }^{19}$ Ikhwan al-Safa', Rasa'il I khwan al-Safa'’ III, 201. 
with the whole part in various kind, various ankle and condition with a different accident; that the law of natural force that occurred to the whole part of universe is as the law of human soul that occurred to the whole part of his body and ankle."20

The complexity of the body of the universe is the same as the complexity of human body. Every physical law, whether emotional, intellectual and intuitive on human was also on universe. This mean that if human be hurt so that he will be in pain, and so as universe that will be in pain or disturb when it's being hurt and disturbs. Man emotional response if he being disturbs, he will get anger, and so with universe that has it own emotional responses. But sometimes we as human are not sensitive toward the emotional, intellectual, and intuitive responses that universe gave to us.

Besides that, ecological view of Ikhwan al-Safa' also can be traced from their concept of human, which concretely positioned as a subsystem of the universe. The philosophical teaching that states that human is little universe is actually wanted to assert the position of human as part of the universe and also stating the perfection of human in front of the other creatures.

Human as small universe is particularity in universality, but on the other hand, human is unique because he is the particular that has the universal elements. Human as small universe is part of this great universe. Human is part of macro cosmos. Therefore, universe cannot be posited randomly. Universe is human working-partner in building a proper and happy life. Likewise teamwork, so that human should cooperate with universe under the surveillance of God as the supervisor and controller and guide.

${ }^{20}$ Ikhwan al-Safa', Rasa'il I khwan al-Słafa', III, 213-214. 
Human is said as small universe, it means that human is the universe itself. So human should be friendlier to the universe because human is the universe itself, human is the other kind of universe, the small one off course. When there is a destructive process that done by human toward universe outside of it, human indirectly has vanished himself. This is because first, there are parallelism between human and universe.

Second, human is the miniature or micro replica of the universe. The whole complexity of the elements of the universe has also had in human body (organ). Universe has the mineral element, so has human. Universe has floral element, so has human. Universe has animal element, and so has human. And universe had a solid spiritual element, and so does human who's believe as the spiritual creature. So, the complexity element of the universe is the same as the complexity of human elements.

It means that human has to be more empathy with universe, or sympathy to the universe; because between human and universe, both have the similar elements. Therefore, human should be friendlier and knowing universe closer; because human relationship with universe is a parallel ontological relationship.

In writing this article, the author relies on the hypothesis that the main cause of various environmental crisis is because modern man abandoned holistic worldview. Modern man ignores the view that all existing entities in the universe essentially have natural relationship as an interrelated system and ontological hierarchy. Man is part of a large family and a subsystem of the universe. The universe is essentially organic, living, and has spiritual side, but modern man has reduced this fact and regarded universe as a big machine that no longer has the spirit and life. 
This kind of holistic view has been neglected and replaced by the anthropocentric worldview which is reductive, mechanistic, secular, and capitalistic. In connection with this problem, the search and formulation of ontological basis for environmental conservation and ecological awareness should be done by explaining the essence of the universe and its various entities.

The search for what is the essence of the universe and its various entities is part of the philosophers and scientists effort, especially classic philosophers and scientists, to study the philosophy of nature. In connection with this philosophy of nature, cosmology is a scientific discipline that examines the nature based on metaphysical perspective. Cosmology can refer to a particular model or idea about the cosmos, but the term generally refers to the science or philosophy dealing with the nature of the large scale universe ${ }^{21}$. The cosmological view deals with the ultimate causes of the universe, its origin, constitution, and qualitative content. According to Seyyed Hossein Nasr, in traditional doctrines, cosmology is always concerned with the application to the cosmos of universal principles which are of metaphysical universe. ${ }^{22}$

In technical term, cosmology in the perspective of Islamic scientific tradition is able to reveal spiritual sides of the universe, which so far has been ignored by modern people through modern science. In modern science, in the end, cosmology must contain empirical-materialistic reductionism. So it is true what Nasr said, that in the modern world today, cosmology is only a name, because it has been reduced by scientific orthodoxy, often called scientism.

${ }^{21} \mathrm{M}$. Watts, Eco-Cosmology, www.cosmology-awakening.com

${ }^{22}$ Seyyed Hosein Nasr, Islamic Life and Thought..., 83. 
However, this study will investigate Ikhwan al-Safa's view of metaphysical-cosmology. To Ikhwan al-Safa', the existence of physical universe cannot be separated from the existence of spiritual entities such as the active intellect, the universal soul, the prime substance, and pure forms. ${ }^{23}$

\section{The holistic worldview of Ikhwan al-Safa's cosmology}

I khwan al-Safa's cosmological view can be traced in detail in Rasail, $16^{\text {th }}$ epistle entitled al-sama wa al-'alam. ${ }^{24}$ I khwan al-Safa were looked this universe as a whole entity. They called it one universe ('alam wabjd). ${ }^{25}$ In another explanation, They referred to the universe as a single body filled by a single soul. ${ }^{26}$

I khwan al-Safa' analogized the universe as a city. They also compared it as an animal, or as a human. As a city, the universe has its own system that were interconnected one to each other. Similarly, when this universe considered as humans, then between the organs to other have a connection and a very close relationship. When the hand was injured, then the whole body feels the same. This view was strengthen up the principle of the unicity of nature, which had been expressed by Seyyed Hossein Nasr in his work An Introduction to Islamic Cosmological Doctrines. ${ }^{27}$ That is, the concept of the unity of

\footnotetext{
23Ikhwan al-Safa', Rasa'łl I khwan al-Săfa'; III, 330-331.

${ }^{24}$ The full title of this epistle is al-Mausumah bi al-sama wa al-'alam fi łslah/al-Nafs wa Tahdhib al-Akhlaq. (The Epistle which named Heaven and Universe with the goal of Soul Cultivation and Moral Improvement). Rasa'il I khwan al-Słafa'; II, 31.

${ }^{25}$ Rasa'il, I, 146; Rasa'il, II,. 398; Rasa'il, IV, 42; Risalah al-J ami'ah, Beirut: Das Słdr, 1974, 534; See also, Risalah al-J ami'ah (ed. Arif Tamir), 299.

${ }^{26}$ Rasa"il, II, 31.

${ }^{27}$ See S.H. Nasr, An Introduction to Islamic Cosmological Doctrines, Cambridge: Harvard University Press, 1964. 4-5. See and compare with 'Abd al-Latif Muhammad al-'Abd, al-Insan fi Fikr Ikhwan al-Safa'; Cairo: Dar al-'Ilm li al-Thaba'ah, 1976, pp. 64-69. In this work, al-'Abd alWahdah use the term wahdlah al-'alam (the unity of universe) as part of Ikhwan al-Safa's core teachings.
} 
the universe in relation to the interrelationships between the elements with various other elements in nature.

The first step that need to be described in this article is the division of the universe entities conducted by Ikhwan al-Safa into two parts: the first is a spiritual entity (al-jawahir al-ruhaniyyah) which is on a spiritual world, or mentioned as the transcendent world (al-'alam ala'la), namely the celestial world. While the second is a physical entity (al-jawahir al-jismaniyyah) which are classified in two other world, the upper world and the lower world (al-'alam al-sufla), namely orbits, the stars, as well as the world that experiencing the natural process of generations and corruptions that lies beneath the moon, or often referred to as the sublunary universe, that is terrestrial universe. All of these has contained in one universe. ${ }^{28}$ Among these worlds has a harmony and plural harmony (tanasub muta'addid). ${ }^{29}$ These harmonies cause the strong interconnectedness among them. ${ }^{30}$

These things what distinguished between Almighty God as the Creator to the universe. When a single God with His unity, then the universe had a matching-equivalent and it partners in the multifaceted. In al-Risalah al-J ami'ah stated,

$$
\begin{aligned}
& \text { و له في العالم السفلى مثال إذ كان كل شيء مما دون الباري سبحانه زوجين } \\
& \text { اثنين ليكون هو الواحد الفرد الصمد، الذي لم يلد و لم يولد. }
\end{aligned}
$$

\footnotetext{
${ }^{28}$ Rasa'il, Beirut: Dak Sadr, III, 237; 352; 361. See also Risalah al-Jami'ah, 373-374; see and compare with George Periggo Conger, Theories of Macrocosms and Microcosms in The History of Philosophy, New York: Columbia University Press, 1922, 47. He uses three terms to describe Ikhwan al-Safa' cosmological scheme; spiritual stages, the intermediate stages, and the lower stages.

${ }^{29}$ Wajih Ahmad, al-Wujud 'inda I khwan al-Săfa', Iskandaria: Das al-Ma'rifah al-J aøni'ah, 1989. 185.

${ }^{30}$ From the beginning I khwan al-Safa' has been introduced the theory of al-Tanasub fi al-'Alam or the theory of al-nisbah, which is the theory of harmony and the natural harmony. For them, the plurality of universe coexists with harmony. If we compared, this natural harmony like the harmony of song's tones and sound of music. See. Rasa'il, I, 252.
} 
"And in spiritual world (transcendental) had similarities in the physical realm, but all things outside the God Almighty, there were two in pairs (zawjayin ithnayn), to prove that God is one, unique, and single, Who begets not, nor was He begotten".

While God was the opposite to universe, as it believed by the prophets and the philosophers, expressed as a single reality in many ways. Precisely duality and composition of the universe would be a proof of His oneness. I khwan al-Safa' explained:

"The prophets and philosophers have determined that Allah the Most Noble and Great, which has no allies and no one like him, is a single reality in many ways. While everything besides Him which are the existents of the universe are two in pairs (coupled), arranged (composed), and complex ". 32

When the spiritual universe had universal intellect, the physical universe had a particular intellect. While the Universe had a spiritual universal soul, the physical universe had a particular soul. ${ }^{33}$ Likewise with the existence of original matter (al-hayulagl-ula) in the spiritual realm, then a partner in the physical universe of matter is lower universe (alhayularal-sufliyyah). The whole entity had ties and interrelationships with each other, and be within reached of God encompasses. In his explanation, Ikhwan al-Safa' said, "Everything that manifests itself is entirely a bond and relation one to another. And Allah's Amr encompasses all". ${ }^{34}$

\footnotetext{
${ }^{31}$ Risalahal-J ami'ah, 351. See also J ami'ah al-J ami'ah, 79.

32See Rasaił, I, 251

$$
\begin{aligned}
& \text { له، واحد شبه ولا له شريك لا الذي -عزوجل -الله بأن و الفلاسفة -عليهم الله صلو ات -الأنبياء اتفقت قد أنه } \\
& \text { مؤلفة ومر كبة مثنوية الموجودات جميع من سواه ما كل وأن الوجوه، جميع من بالحقيقة }
\end{aligned}
$$

${ }^{33}$ This universal soul is the soul that includes and flows in celestial orbital substances. While the particular soul includes and flows into all of the organism's entities in the physical universe (animal, plant, and mineral).

${ }^{34}$ Ikhwan al-Safa', al-Risalah al-J ami'ah, 352; see also Rasa'il, I, 404; Rasa'il, IV, 339.

فالأشياء كلها مرتبطة بعضها ببعض، و أمر الله محيط بها كلها 
In more detailed I khwan al-Safa explained,

"While the philosophers and those who are firmly grounded in knowledge, they can see -through their clarity of soul and light of intellect- nonphysical (spiritual) substances flows in natural objects. It showed the activity and its influence on these objects according to the relationship between each other. That influence is the evident in every physical objects according to the power, effort, and ability. And this spiritual entity is the core of each creatures. Therefore, any activity that seems to physical entities, then surely learning on its spiritual entity." ${ }^{35}$

Shortly, Ikhwan al-Safa' defines the spiritual world as everything that can be perceived and abstracted by mind. While the physical world is anything that can be perceived only by the senses itself. Spiritual world cover orbital's world which is a physical world ${ }^{36}$. As this orbital world involves sublunar world that consisting of the elements and derivatives entities of minerals, plants, and animals.

According to Ikhwan al-Safa', creation of a variety of physical entities is done gradually in accordance with the period (al-Duhur) and time (al-Azman). While the creation of various entities-spiritual transcendence happens at once in one time without going through the process of space, time, and matter. ${ }^{37}$ In Nadiah Jamaluddin's explanation, God had created the potential presence (bi al-quwwah) of the whole entities of this world, both spiritual and physical entities-simultaneously. But

\footnotetext{
${ }^{35}$ Ikhwan al-Safa', al-Risalah al-J ami'ah, 376.

وأما الحمماءو النجباء الراسخون في العلم فشاهدوا بصفاء نفوسهم و نور عقولهم، جواهر غير جسمانية علامة

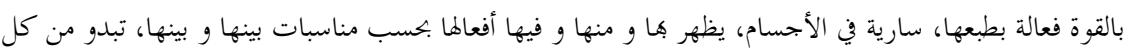

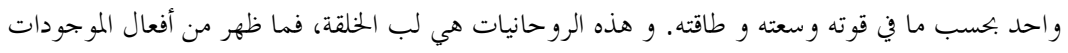
吕

${ }^{36}$ Rasa'fl, III, 362.

${ }^{37}$ Rasa'yl, III, 352.
} 
after that, God actualized the potential of the entire universe of existential sequentially, one by one so entirely embodied in an actual. ${ }^{38}$ What was meant by this things is a form of existential potential (shuwar) and archetype (a'yan). ${ }^{39}$ Ikhwan al-Safa' mentioned that the existence of the entity as a whole is potentially within the universal active intellectual.

Starting from the creation of the spiritual-transcendent and continue on the creation of physical-physic of nature. Therefore the existence of spiritual nature earlier and begun more earlier than the existence of physical-physic of nature. In the theory of emanation Ikhwan al-Safa', explicitly stated, that the universal mind is the first beam that comes directly from God. And through this universal sense of all the entities realized. Within this universal sense, all forms of entities exist potentially. This is the forerunner to the existence of all entities of nature manifested in an actual manner. ${ }^{40}$

\footnotetext{
${ }^{38}$ Nadia J amaluddin, Falsafah al-Tarbiyah 'inda Ikhwan al-Safa'; Cairo: Das al-Kitab al-Mishr, 2002, 155.

${ }^{39}$ Further explanation about the origin of variety form of this universe from it shape and archetypes presented as follows:

$$
\begin{aligned}
& \text { فقد بان بذذا المثال أن الموجودات كلها صور غيريات، وهي أعيان الأشياء، وأنها متتاليات في الحدوث والبقاء، كتتلالي }
\end{aligned}
$$

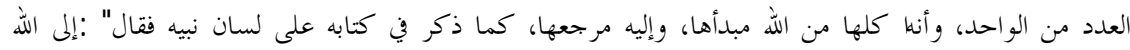

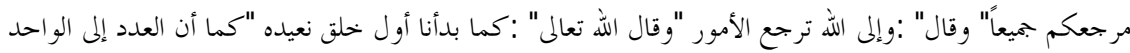

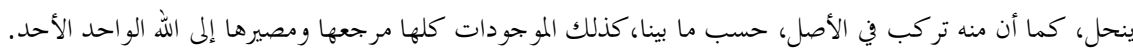

"It seems clear by this example that the existents were different shapes. It is the archetypes of all things. Everything happens and takes place in sequence, as sequence numbers that start with number 1 . And it all comes from God as a place (point) of origin and to Him as the return of all. As stated in the Qur'an through the oral of his prophet. He said: The return of you (all) is to Allah (QS. Al-Małdah: 48, 105). Allah also says: And to Allah return all matters (for decision). (QS. Al-Baqarah: 210). Allah also says: As we begin the first creation, we shall repeat it (QS. alAnbiyał 104). As all the numbers will go back to number 1 , as well as from number 1 all the numbers composed at first, as we have explained. Similarly, all entities form, where the return to God Almighty and Single “

${ }^{40}$ See al-Risalah al-J ami'ah, p. 370. that stated:

وهو جوهر بسيط روحاني، فيه جميع صور الموجودات... 
Hierarchically, I khwan al-Safa's spiritual entities as a spiritual structure divided into three kinds: 1 . Universal Active Intellect (al-'Aql al-Kulli al-Fa'al); 2. Universal Soul (al-nafs al-Kulliyyah); 3. Original matter (alHayula>al-Ula). Universal intellect is a simple substance that can be captured the essence and reality of all things. While the universal soul is a simple active substance (fa'alah) and has the power to know ('allamah). The Original matter interpreted as a simple substance (jawhar basity a passive (munfa 'il), which can be perceived as rational (ma'qul) and received variety of forms.

While the physical entity consisting of three kinds: first, the objects orbital (al-ajram al-falakiyyah); second, four natural elements of fire, air, water, and soil; third, the third derivative of the organism, animals, plants, and minerals.

\section{Tawhid as a metaphysical basis}

The view of tawhid was very dominant in giving influence to I khwan alSafa' cosmological thinking. Even the principle of tawhid was the main basis of the whole edifice of Ikhwan al-Safa's thought. Inauguration of the principle of tawhid as the basic cosmological foundation relied on the explanation of Pythagoras's numbers theory and his followers.

In one of paragraph of Rasa'il, Ikhwan al-Safa' has cited a Pythagoras's view about the link between the theory of numbers with the concept God's unity,

"Verily in the knowledge of numbers, as well as the origin of numbers growing process from number one before the number two, there was knowledge of the Allah's oneness, the Exalted and Almighty. While the knowledge about the number characteristic, order and structure, there was knowledge of all the entities of God's crea- 
tures in this universe as well as the knowledge about their creation, composition, and hierarchy." ${ }^{41}$

The quotation above confirms to us that in order to gain knowledge about the reality of the universe, and then the first thing that must be done was to believe in the oneness of God the creator of the whole entity of this universe. As if you want to know about the different kinds of numbers, characteristics, and structure, it must be preceded by gaining knowledge about the number one.

A dictum of Pythagoreans mentioned that the reality of the universe was constructed in accordance with reality and characteristic of the numbers. This was echoed by Ikhwan al-Safa' as an initial framework in looking at the reality of this universe as a whole. In this case I khwan al-Saf'a has cited the views of the Pythagorean philosopher with the following statement,

“Therefore, the Pythagorean's philosophers said: The entities of this universe in accordance with the reality and the numbers characteristic. If anyone understands the reality, numbers and their types of characteristics, then he will gain a great clarity and wisdom that the formation of the universe was consistent with the privilege of the numbers". ${ }^{42}$

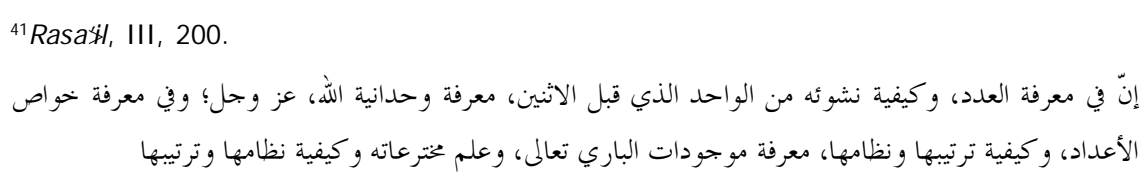

${ }^{42}$ Rasa'il, I, 140;

فمن أجل هذا قالوا (الحكماء الفيثاغورثيين): إن الموجودات بحسب طبيعة العدد وخواصه .فمن عرف طبيعة العدد

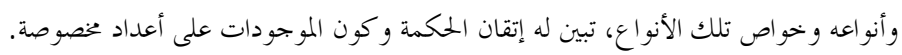
see also Rasa'il, III, 178-179:

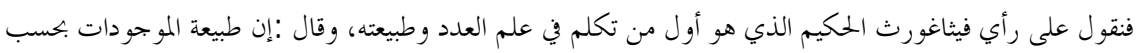

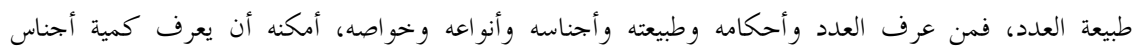
المو جودات وأنواعها. 
That number began or came from 1 , and from 1 came the other numbers such as $2,3,4,5,6,7,8,9$, and so on. These numbers composed a plurality (al-kathrah) and diversity. While these numbers have been well formed and arranged, then the existence of one did not change and remained unaffected by the plurality of the other numbers were derived from it.

In the view of Ikhwan al-Safa', the concept of number one was being understood as something that has no part at all, and was not divided. ${ }^{43}$ So everything that was not divided and part away was one. Or one that was unity where there no other things attached to them.

God is single and one, then His being likened by the I khwan al-Safa' as a single figure that became the base of the existence of the other numbers. While the entities of this universe were like the numbers after the number one that came from number one's being. The existence of number one was before the number 2, 3, 4 and so on. I khwan al-Safa' explained further about the relationship between God and the other entities in the universe, that is when God was like the number one, then the existence of a universal active intellect was like the number 2, while the universal soul like number 3 , then the original matter as number 4 . All of this entity was a spiritual entity and was not a physical entity.

The explanation above for Ikhwan al-Safa was the most powerful argument to prove the existence of God as a single entity and confirmed the principle tawhidullah. Number one that exist before number two, although it will break down the numbers from its presence in others, but its existence will not change and remain a single, nor divided. Likewise the existence of the Almighty God. Though He, Himself who created everything from the light of His unity, and then develop

${ }^{43}$ Rasa'il, I, 49 
His creation to be plural and diverse, yet His presence remains one and single, no changes on the presence of His before He created everything that laid in this universe.

Therefore, this view would like to emphasize the differences between the One and the many. Which the one was God, while the many was universe's entities other than God's. When God Almighty created very much creatures and entities of the universe well ordered and arranged them neatly as the order of the numbers, then this thing becomes an evidence of $\mathrm{He}$ as The One. Inauguration of universal plurality took on the facts and evidence about the existence of The Almighty God.

Ikhwan al-Safa' confirmed that Unity of God was mut\}laq, He's markedly Single from various types and meanings. There was no accompanying His unity nor was resembles him. While the entity of the universe in pairs and even composed by plural composition of the various entities. For an example, when God created the body, then at least there were two entities that formed it, we called as matter and form. When God had been recognized as something that the One from all sides, then there is no other than He is the Almighty God.

\section{The soul of universe theory}

One other thing that also underlined the cosmological view of I khwan al-Safa' was the existence of a universal soul who inhabits this universe. Even the study of this issue became one of the most important scientific fields for Ikhwan al-Safa' as a branch of metaphysics.

In one explanation they stated, it was declared that metaphysics has 5 branches of science, which were (1) theosophy, knowledge about the God and His unity, (2) Angelology, knowledge of the angels who were defined as simple intellectual substances; (3) Psychology, the 
knowledge of souls embedded in the universe, (4) Political (5) Eschatology, knowledge of life after death and Resurrection. ${ }^{44}$

In this description, the author wanted to focus on I khwan al-Safa's psychology view which directly has became the basis for cosmological thinking. In their view, psychology was not only conceived as a scientific discipline that examines the particular souls which were attached to humans. But further, they defined psychology as a science that examines all the souls that exist in this universe, no matter it was the universal soul or particular souls. In their explanation, they stated,

"Psychology was the science of the souls and spirits that were attached to the objects of the universe; even it was an orbital objects or objects in sub lunar universe, from the upper end of the outermost orbit until the end of the center of the earth. In addition, this knowledge was also knowledge of how the souls of those orbits rotated, moved the stars, and arranged the presence of animals and plants, its incarnation in the body of animals, and how to awaken the body after death."45

In the paragraph above, it seemed very clear that I khwan al-Safa's cosmological view emphasizing the role presence of soul and the movement of this universe. Therefore, the physical body of the universe required the existence of the soul to move and turn. The knowledge of the soul was derived from psychology that whole and holistic and made the reality of soul as a part of the object of knowledge.

\footnotetext{
${ }^{44}$ Rasa'il, I, 272-273.

${ }^{45}$ Rasa'il, I, 234.

علم النفسانيات، وهي معرفة النفوس والأرواح السارية في الأجسام الفلكية والطبيعية، من لدن الفلك الخيط إلى منتهى

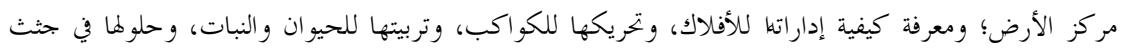
الحيو انات، و كيفية انبعاثها بعد الممات.
} 


\section{The concept of universe love}

For Ikhwan, the universe was alive and driven by the inherent power which God gave to all elements in this universe. I khwan al-Safa' called it love or al-'ishq. In a special epistle, I khwan al-Safa' discussed in depth about this theme, which was the essence of love, love of life, and the fever to God. This theme became their special concern, because for them the reality of love was there in the universe, centered in many of soul's character, both in the universal soul or particular soul. And its presence will always there as long as the entities of this universe exist.

Many of the philosopher and scientist's opinion whose provide a definition the essence of love. Some of them were presented in the treatise of fi Mahiyah al-'Ishq. However, the most powerful views on love was held by the Ikhwan al-Safa' that stated that love is a passion and a strong desire to coalesce (shiddah al-shawq ila al-ittih dd), which was a situation that makes a lover want to be closer to the one they loved. ${ }^{46}$ To illustrate the depth of their about this definition of love, Ikhwan al-Safa recited a suspected love poem that comes from the Sufi poet I bn al-Rumi as follows,

"I hugged her and my soul fell in love with her, whether, after hugging, I'm being away? I kissed her lips so my longing will disappear, but my love grew much more. It was as if my heart did not heal the pain, unless it had seen that two souls were united." 47

The key word in the meaning of love as mentioned above was the union (al-ittihad). The unification was a state that blew from the soul and a part of spiritual activities. Because it can only be done by spiritual

\footnotetext{
${ }^{46}$ Rasa'il, III, 272.

${ }^{47}$ Rasa"il, III, 272-274.

أُعانقها، و النفس بعد مشوقة إليها، وهل بعد العناق تداني؟ وألثم فاها كي تزول صبابتي، فيزداد ما ألقى من الهيمان

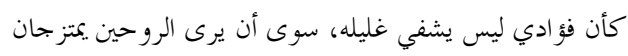


entities. Therefore, the desire to unite was part of the attributes possessed by the souls. The physical entities will not be able to perform the unification, because it was limited just to make an approach (almujawarah), the mixture (al-mumazajah), and contiguity (almumasah), and no more than that. ${ }^{48}$

Nevertheless, the souls were capable of doing this union and flows across the physical universe. Therefore, through the love and the desire to be united, some bodies of the universe has been turned on and driven by these souls. But who's the love object of this soul, who's the person that needs to be loved and hoped to unite by this souls?

I khwan al-Safa' stated that the desire to unite was addressed to God the Creator, whether it was done by the particular souls and universal soul. He was the main and first object of love (al-Ma'shuq al-Awwal). God was the sourced (al-mabda') of love's existence in this universal entities, as well as He was the returned place (al-ma'ad) of love.

Love of the universe - especially the higher universe entities ('alam al-'alawip represented by the universal soul of God likened by Ikhwan al-Safa' as love among khawas/which consisting of the pious and wise men (philosophers). The signs were when they see the beauty and perfection in this physical world, they love the beauty of it because of the beauty and perfection in this world was created and derived from the Supreme Beautiful Creator. Therefore, their love will turn to God as the Creator of the All Wise and Knowing. ${ }^{49}$ They felt the peace and strong ties to the Lord when they saw His creation in this world. In fact they were trying in earnest to resemble what God has done in this universe through a variety of works that they create, to imitate God's good deeds, good speech, action, science, and charity.

${ }^{48}$ Rasa'il, III, 273.

${ }^{49}$ Rasa'il, III, 284. 
Therefore the basis of this universal of love was resemblance of the Supreme Reality, God the Creator. Particular spirit of the philosophers and wise men seek seriously and hope to be able to resemble the universal soul and God the creator in every deed, science, charity, and their morals. While the universal soul earnestly in order to resemble God the Creator in its activity when moving the orbits, moving the stars, and form a whole entity of the universe. It was all done on the basis of love, obedience, and servitude to Allah the Lord Creator of the Universe.

Therefore, all movements and activities of the universe was constituted by a sense of love and hope resemblance activities themselves with the activity of God. The God' love has moved and brings the whole entity of this universe. In this case the Ikhwan al-Safa' quoting the views of philosophers, who stated:

'Verily, Allah is the first love object, while the orbits and the stars rotating as longing to Him, and love to remain an eternal and timeless in the most whole with Him, in the most perfect destination to $\mathrm{Him}$, and eternal in the end the most important to Him". ${ }^{50}$

Furthermore, I khwan al-Safa' explain the strong motivation why the sense of love that belongs to universal soul was so powerful and had made it moving the universe, the orbits, run the stars and planets, and turn on the various entities of the universe both in the higher universe and in the lower universe. The answer was because of the passion and strong desire to manifest the goodness, primacy, perfection, pleasure, and happiness that only can be found in the spiritual universe and cannot be expressed by words.

\footnotetext{
${ }^{50}$ Rasa'il, III, 285.

إن الله هو المعشوق الأول، والفلك إنما يدور شوقاً إليه، ومحبة للبقاء والدوام المديد على أتم الحالات، وأكمل الغايات، وأفضل النهايات.
} 
The activity to move and turn the universe was a part of the goodness and primacy manifest that makes it feel pleasure and happiness. The source and the estuary of all goodness, primacy, perfection, pleasure and happiness was derived from the emanation of God (faydh Allah).

All the movement and life of the universe since the active intellectual universe, the universal soul, and the original matter in the highest universe ('alam al-a'la), the objects in the highest universe, up to the physical entities in sublunar universe in the lowest universe ('alam alsufla) nothing less it has been driven by a love that was embedded in all of the main and first object of love, namely God the Creator.

The author would like to end the discussion of universal love towards the Lord God Almighty Creator of this by quoting the essence of I khwan al-Safa's sentence which states,

"It was clear that Allah was the first object of love, and all the entities of existance in this universe eager longing to Him, comes down to Him, and everything will return to Him. Due to the presence of Him, then these entities of existance turn into being, eternal, eternal, and perfect. Because He was the pure existance, which in Him inherent to immortality, eternity, eternity, wholeness, and the strong perfection". 51

\footnotetext{
${ }^{51}$ Rasa'fl, III, 286

فقد تبين بما ذكرنا أن الله هو المعشوق الأول، وأن كل الموجودات إليه تشتاق، ونوه تقصد، وإليه يرجع الأمر كلّله.

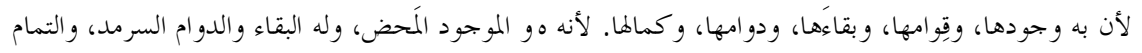
والكمال المؤيد
} 


\section{Bibliography}

Ahmad, Wajih. al-Wujud 'inda I khwan al-Safa's Iskandaria: Dasal-Ma'rifah al-J ami'ah, 1989.

al-'Abd, 'Abd al-Latif Muhammad. al-Insan fi Fikr I khwan al-Słafa'’Cairo: Das al-'IIm li al-Thabałah, 1976.

al-Attas, Syed Muhammad al-Naquib. I slam dan Sekularisme. Bandung: Penerbit Pustaka, 1981.

al-Safa', I khwan. al-Risalah al-J ami'ah. ed. Mushtafa Galib. Beirut: Daץ Sథ̊dr, 1974.

al-Safa', Ikhwan. Rasa'ł Ikhwan al-Safa'> Qum: Maktab al-A'łam alIslami> 1405.

Bakar, Osman. Environmental Wisdom for Planet Earth: The Islamic Heritage. Kuala Lumpur: Center for Civilizational Dialogue University Malaya, 2007.

Capra, Fritjof. The Turning Point: Science and Society, and the Rising Culture. Toronto-London-New York-Sydney: Bantam Books, 1983. Conger, George Periggo. Theories of Macrocosms and Microcosms in the History of Philosophy. New York: Columbia University Press, 1922.

Gilkey, Langdon. Nature, Reality, and the Sacred The Nexus of Science and Religion. Minneapolis: Augsburg Fortress, 1993.

Heriyanto, Husain, "Respon Realisme Islam terhadap Krisis Lingkungan", in Fakhruddin M. Mangunjaya, dkk (ed.). Menanam Sebelum Kiamat: Islam, Ekologi, dan Gerakan Lingkungan Hidup. Jakarta: Yayasan Obor Indonesia, 2007.

Jamaluddin, Nadia. Falsafah al-Tarbiyah 'inda Ikhwan al-Safa'? Cairo:

Das al-Kitab al-Mishr, 2002. 
Mangunjaya, Fakhruddin M., dkk (ed.). Menanam Sebelum Kiamat: Islam, Ekologi, dan Gerakan Lingkungan Hidup. Jakarta: Yayasan Obor Indonesia, 2007.

Muhammad, Sabir Abduh Aba Zayd. Fikrah al-Zaman 'inda I khwan alSafa's Dirasah Tahliliyyah Muqaranah. Cairo: Maktabah Madbuli, 1999.

Nasr, Seyyed Hossein. An Introduction to Islamic Cosmological Doctrines. Cambridge: Harvard University Press, 1964.

Nasr, Seyyed Hossein. Islamic Life and Thought. London: George Allen \& Unwin Ltd, 1981.

Nasr, Seyyed Hossein. Man and Nature: The Spiritual Crisis in Modern Man. ABC International group Inc., 1997.

Pasha, Ahmad Zaki. Mausu ah al-'Ulum al-'Arabiyyah wa Bahth 'an Rasa'ł I khwan al-Słafa's Bulaq, Egypt: al-Matha'ah al-Amisiyyah, $1308 \mathrm{H}$.

White, J r, Lynn, "The Historical Roots of Our Ecologic Crisis", Science, Volume 155, Number 3767 (10 March 1967).

Wimberley, Edward T. Nested Ecology: The Place of Humans in the Ecological Hierarchy. Maryland: The J ohns Hopkins University Press, 2009. 